\title{
緑化法面に侵入したクズ（Pueraria lobata）の駆除試験
}

\section{田中 淳 1) - 堀江直樹 1) - 早川信光 ${ }^{2)}$}

1）日特建設株式会社 jun.tanaka@nittoc.co.jp

2）国土交通省中部地方整備局小里川ダム管理所

\begin{abstract}
摘要 : 施工後約 10 年が経過してクズに覆われた緑化法面において, 使用方法が異なる 3 種類の除草剤（散布 ・滴下・挿入）を選択し，駆除手法確立のための試験施工を実施した。その結果，全面散布タイプの除草方 法では，クズ以外の植物にも影響を与えるが， 1 回の散布でも翌年 5 月に再生した株頭はなかった。株頭処 理タイプの滴下型では, 翌年の 5 月には若干再生した株頭が確認された。挿入型では, 再生した株頭は確認 されなかった。しかし，施工時期によっては滴下型の効果が期待できる場合もあった。除草時期と除草剤の 特性，クズの生態などを考慮することで，緑化法面におけるクズを駆除できる可能性が示唆された。
\end{abstract}

キーワード : 除草剤, 維持管理, 偏向遷移, 植生誘導工, 防除, クズバスター

\section{1. はじめに}

クズ (Pueraria lobata (Willd.) Ohwi) の駆除に関する報 告は, 造林地や公園, 草地において実施した除草凨の効果に 関するものが多い。造林地では, 樹木が大きく生育し, 林床 が暗くなればクズの生育を抑制することができるため, 生育 初期段階で刈り払いや除草剂散布を実施すれば解決できた。 また，公園などでは容易にメンテナンスができるため, ツル 切りや根元切断などでクズの繁茂を制御することが可能であ る。しかし，切土法面では，生育基盤厚さに限界があること や傾斜地であるため樹木の樹高も数 $\mathrm{m}$ と生育が抑制され, ク ズが常に生育できる光環境である。さらに, 急傾斜法面に侵 入したクズの駆除作業は容易でない。そのため, 一度クズが 侵入した場合の被害は甚大となる。

一方で生物多様性の観点から, 植生誘導工（自然侵入促進 工や森林表土利用工）の利用が増えている。これらの方法は 施工の容易さ, 経済性に優れるなど有用性に優れた方法であ る。しかし, 植物侵入の不確実性や発生する植物の不明瞭性 など問題がある5 のも事実である。このような条件は, クズ の侵入生長に適した環境下であり, 植生誘導工の緑化ではク ズが発生する確率も高い3)といわれている。

クズが一度侵入すると, 正常な植生遷移が妨げられ, 長期 にわたりクズ群落が続き, 偏向遷移することが指摘 ${ }^{1}$ されて いる。そのため, クズの侵入を防ぐ対策と共に, クズが侵入 した場合の駆除技術を確立しておくことが重要である。

本報告では，急傾斜法面に侵入したクズを現実的で確実に 駆除する技術を見いだすために, 試験施工を実施し一定の効 果が確認できたので報告する。

\section{2. 現場試験}

\section{1 現場概要}

クズ処理実験を実施した場所は, 岐阜県瑞浪市の小里川ダ 么堤体左岸上部法面である。現場条件を表- 1 に示す。この法 面は, 1996〜1997 年に植生工を実施し, クズ駆除工事を実 施するまで 10 年以上が経過している。このダム法面では,

「植樹による新たな生態系の回復」をコンセプトに樹林化対 策工事を行ってきた ${ }^{2,4)}$ 。施工断面を図-1 に示す。

クズの発生は, 経年写真から判断すると, 小段の植栽工の 施工時に使用した客土中に含まれていたと予想され，1 年後 の 1997 年の写真にはクズの繁茂が確認された。その後クズ の生育範囲は拡大を続け, 2006 年夏には法面の 8 割程度が クズで覆われる状態となった。クズの駆除対策の実施は, 今 回が初めてではなく, 工事期間中の 2000 年と 2002 年の秋季 の合計 2 回, 後述するイマザピル含浸クズ専用除草剂で駆除

\section{表-1 現場条件}

\begin{tabular}{|c|c|}
\hline 所 在 地 & 岐阜県瑞浪市 \\
\hline 施工地標高 & 約 $430 \mathrm{~m}$ \\
\hline 緑化工事内容 & \\
\hline 位 & 北向き \\
\hline 勾配 & $1: 0.5$ (63度程度) \\
\hline 施工時期 & 1996年～1997年 \\
\hline 緑化基礎工 & 連続繊維補強土工 $\mathrm{t}=20 \mathrm{~cm}$ \\
\hline 植生工(播種) & 植生基材吹付工 $\mathrm{t}=3 \mathrm{~cm}$ （総発生期待本数 : 1500 本 $/ \mathrm{m} 2$ ) \\
\hline 外来草本 & ジェーングラス, ハードフェスク, \\
\hline 草花 & $\begin{array}{l}\text { コスモス, シキミソウ, カスミソウ, マツカサギク } \\
\text { オオテンニンギク, ハルシャギク, カワラナデシコ } \\
\text { オオキンケイギク, カリフォルニアポピー, }\end{array}$ \\
\hline 植生工(植栽) & ヤマブキ, ヤマツツジ, アセビ（密度 0.5 本 $/ \mathrm{m} 2$ ) \\
\hline
\end{tabular}


表-2 使用した除草剂の特徴

\begin{tabular}{|c|c|c|c|c|c|}
\hline 分類 & \multicolumn{4}{|c|}{ 株頭処理（人力作業）タイプ } & 全面散布（機械作業）タイプ \\
\hline 区分 & & (1) : 涺 & 商下型 & (2) : 挿入型 & (3)散布型 \\
\hline 除草成分 & MDBA液剤 & & & イマザピル含浸 & メトスルフロンメチル水和剤 \\
\hline 使用方法 & 株頭に薬剤 & （液体） & を滴下する & $\begin{array}{l}\text { 除草剤の付いた木針をクズの株頭に打 } \\
\text { ち込む }\end{array}$ & $\begin{array}{l}\text { 水で希釈後に噴霧器で全面に散布す } \\
\text { る。 }\end{array}$ \\
\hline 使用適期 & $4 \sim 11$ 月 & & & 年中使用可（秋〜冬が使用しやすい） & $5 \sim 11$ 月 \\
\hline 特徵 & $\begin{array}{l}\text { 挿入型より } \\
\text { 枯らさない } \\
\text { る。 }\end{array}$ & $\begin{array}{l}\text { も作業性, } \\
\text { 。方, }\end{array}$ & $\begin{array}{l}\text { 生に優れ，植栽木を } \\
\text { 施工時期が限られ }\end{array}$ & $\begin{array}{l}\text { 施工時期を問わず施工でき, 植栽木を } \\
\text { 枯らさないが滴下型と比較して施工性 } \\
\text { に劣る。 }\end{array}$ & $\begin{array}{l}\text { 施工性がよいが植栽木を枯らす危険が } \\
\text { ある。 }\end{array}$ \\
\hline
\end{tabular}

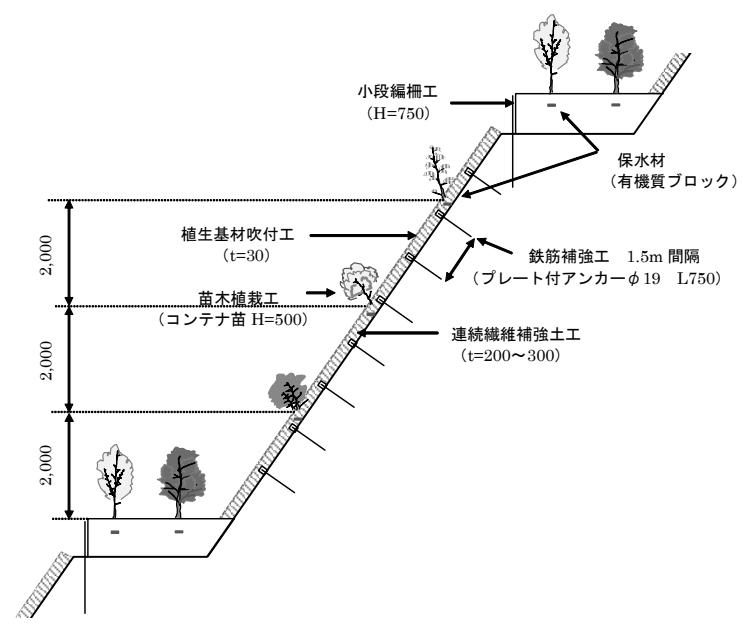

図-1 クズ対策を実施した施工法面の設計断面

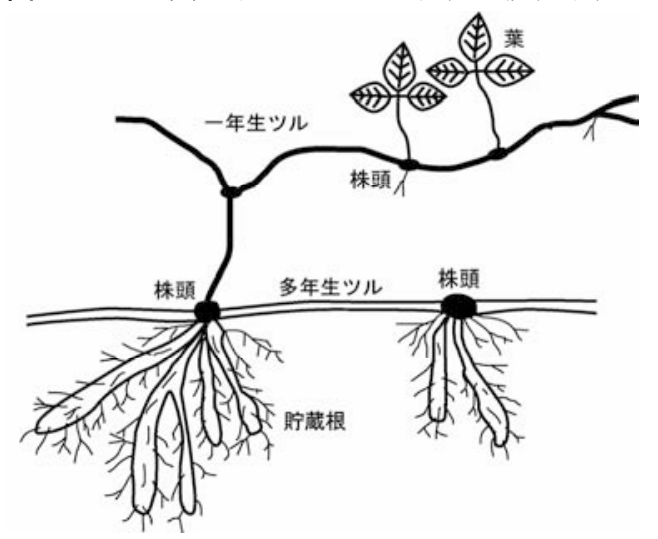

図-2 クズの各器官

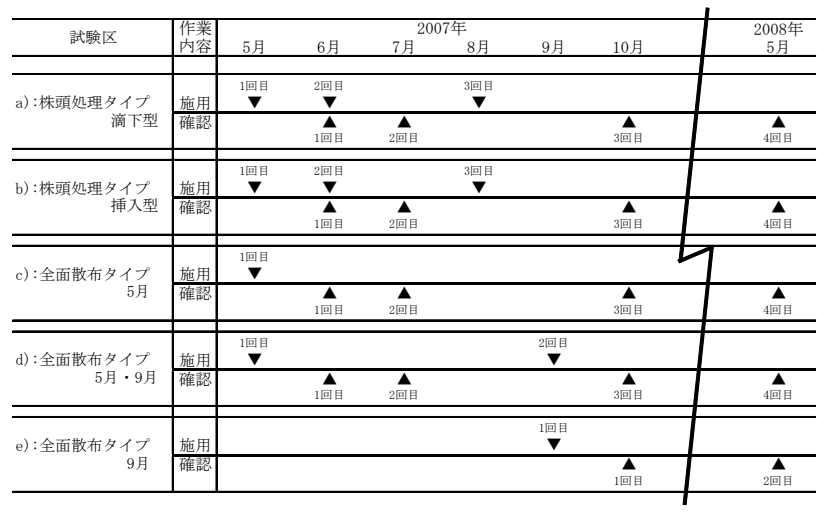

図-3 駆除試験要因と工程
を実施した。しかし，完全に駆除できなかったため被害が拡 大してきた経緯がある。

試験対象とした法面だけでもクズに植被された面積は 4,000 $\mathrm{m}^{2}$ 程度あり, 小里川ダム全体では $10,000 \mathrm{~m}^{2}$ を超す。 これら広大な面積のクズを確実に駆除するためには, 人力を 主体として実施することは効率的でなく無理があると考えら れたことから，除草剤による駆除方法を検討した。

\section{2 試験概要}

\subsection{1 試験目的}

急傾斜切土法面において，クズを制御・駆除する技術手法 を確立するために， 3 種類の除草剤とその最適な使用方法を 検討することを目的とした。

\section{2 .2 使用除草剂}

除草剂は，クズに全面覆われた状態での使用が適する(1)： 全面散布タイプ, 植栽木や周辺植物への影響を抑えられると 思われる，株頭処理タイプの(2) : 滴下型, 株頭処理タイプの (3) : 挿入型の 3 種類の除草剤を選定した。選択した除草剤の 特徵を表-2 に示す。

なお, クズの各器官は図-2のように区分した。全面散布型 の除草剂は, 葉や多年生ツルに直接散布し, 株頭処理タイプ の除草剤は，株頭部分を探し出し直接処理する。

\section{2 .3 試験方法}

法面勾配が 1:0.5, 北向き, 試験前年の 2006 年 8 月の調査 でクズの植被率が $100 \%$ の斜面に, $10 \mathrm{~m} \times 10 \mathrm{~m}$ の試験区を 設置し，3 種類の除草剂を使用し効果を確認した。試験区で は, クズが植栽木に覆い被さっている場所を選定し, 散布処 理を行う試験区では, 植栽木が枯れ, 法面が多年生ツルに覆 われている場所を選定した。

除草剤の使用は, 効果を確認しながら複数回行うことを原 則として, 図-3のように株頭処理タイプは 3 回, 全面散布を 行ったものは 1〜2 回, の処理を行い, 除草剤を使用しなか った対象区と比較し効果を把握した。試験要因は a）株頭処 理タイプ-滴下型，b）株頭処理タイプ-挿入型，c）全面散布 タイプ-5 月散布型， d）全面散布タイプ-5・9 月散布型，e） 全面散布タイプ-9 月散布型, の 5 種類とした。

試験期間は効果の確認も含めて 2007 年 5 月から 2008 年 5 月まで行なった。試験期間中の管理は, 試験区外からクズが 侵入し, 試験区で繁茂しないように駆除を行った。 
表-3 クズの植被率（\%) の推移

\begin{tabular}{|c|c|c|c|c|c|c|c|}
\hline & \multicolumn{5}{|c|}{ 2007年 } & \multicolumn{2}{|c|}{ 2008年 } \\
\hline & 5月 & 6月 & 7月 & 8月 & 9月 & 10月 & 5月 \\
\hline a):株頭処理タイプ-滴下型 & 5 & 1 & 3 & 1 & 0 & 0 & 1 \\
\hline b):株頭処理タイプ-挿入型 & 5 & 1 & 3 & 1 & 0 & 0 & 0 \\
\hline c):全面散布タイプ-5月 & 15 & 10 & 30 & 30 & 40 & 40 & 5 \\
\hline d):全面散布タイプ $-5 \cdot 9$ 月 & 15 & 10 & 30 & 30 & 40 & 0 & 0 \\
\hline e):全面散布タイプ-9月 & 15 & 70 & 100 & 100 & 100 & 0 & 0 \\
\hline f):対象区 & 5 & 50 & 80 & 100 & 100 & 100 & 10 \\
\hline
\end{tabular}

\section{3 施工方法}

\subsection{1 株頭処理タイプ}

株頭処理は，すべて命綱にぶら下がっての作業となった。 樹木が生育しているため, 命綱で 1 回降下しても幅 $3 \mathrm{~m}$ 程度 しか処理することはできなかった。そのため, $3 \mathrm{~m}$ おきに命 綱を設置し，作業員は複数回斜面を降りる作業が必要であっ た。

（1）滴下型

株頭に直接薬剤を滴下する方法で，除草剂が入った容器に ついているボタンを押すと, 液体の薬剤 $(0.25 \mathrm{ml})$ の定量が 滴下できる。直径 $2 \mathrm{~cm}$ 以上の株頭には $2 \sim 3$ 回, $2 \mathrm{~cm}$ 未満 の株頭には 1 回滴下した。一年生および多年生ツルにかかわ らず発見したすべての株頭に滴下した。

(2) 挿入型

薬液含浸長さが $3.5 \mathrm{~cm}$ の, 除草剤が付いた木針を多年生ツ ルの株頭に打ち込んだ。 $5 \mathrm{~cm}$ 以上株頭には 3 本, $2 \mathrm{~cm}$ 以上 $5 \mathrm{~cm}$ 末満の株頭には 2 本, $2 \mathrm{~cm}$ 末満の株頭には 1 本打ち込 んだ。一年生ツルの使用は困難であったため, 多年生ツルの みを処理した。

\subsection{2 全面散布タイプ}

粉末状の除草剤を水で希釈した後, 動力式噴霧器にて小段 から散布した。散布量は, $1000 \mathrm{~m}^{2}$ あたり $10 \mathrm{~g}$ の薬剤を水 1501 で希釈し散布した。

\section{4 調查方法}

調査項目は，クズの植被率と株頭処理の場合は処理した株 頭数，見落とし株数およびその再生株頭数を測定した。見落 とし株は，1 回目（2007 年 5 月）の処理で株頭が確認できず 処理を行わなかった株頭である。再生株頭とは，一度処理し たものが, 再生して一年生ツルを生長させている株頭である。 本報告では，多年生ツルが地上で発根している場所を株頭と して測定し，一年生ツルの株頭は測定していない。

\section{3. 結果及び考察}

\section{1 クズの植被率の推移}

クズの植被率を表-3 に示す。施工前 2007 年 4 月，2008 年 5 月の調査の植被率には多年生ツルの值である。 全面散布タイプ-5 月は，2007 年 7 月にはクズの再生が確
表-4 多年生ツルの株頭処理数

\begin{tabular}{|c|c|c|c|c|}
\hline \multirow{2}{*}{ 調査年月 } & \multirow{2}{*}{ 区分 } & \multirow{2}{*}{ 株頭径 } & \multicolumn{2}{|c|}{ 株頭処理タイプ } \\
\hline & & & 滴下型 & 挿入型 \\
\hline \multirow{3}{*}{ 2007年5月 } & \multirow{3}{*}{ - } & $2 \mathrm{~cm}$ 未満 & 24 & 24 \\
\hline & & $2 \mathrm{~cm}$ 以上, $5 \mathrm{~cm}$ 未満 & 10 & 15 \\
\hline & & $5 \mathrm{~cm}$ 以上 & 0 & 4 \\
\hline \multirow{6}{*}{ 2007年6月 } & \multirow{3}{*}{ 見落 } & $2 \mathrm{~cm}$ 未満 & 2 & 2 \\
\hline & & $2 \mathrm{~cm}$ 以上, $5 \mathrm{~cm}$ 未満 & 0 & 4 \\
\hline & & $5 \mathrm{~cm}$ 以上 & 0 & 0 \\
\hline & \multirow{3}{*}{ 再生 } & $2 \mathrm{~cm}$ 未満 & 8 & 2 \\
\hline & & $2 \mathrm{~cm}$ 以上, $5 \mathrm{~cm}$ 未満 & 10 & 3 \\
\hline & & $5 \mathrm{~cm}$ 以上 & 0 & 0 \\
\hline \multirow{6}{*}{ 2007年10月 } & \multirow{3}{*}{ 見落 } & $2 \mathrm{~cm}$ 未満 & 0 & 0 \\
\hline & & $2 \mathrm{~cm}$ 以上, $5 \mathrm{~cm}$ 未満 & 0 & 0 \\
\hline & & $5 \mathrm{~cm}$ 以上 & 0 & 0 \\
\hline & \multirow{3}{*}{ 再生 } & $2 \mathrm{~cm}$ 未満 & 5 & 5 \\
\hline & & $2 \mathrm{~cm}$ 以上, $5 \mathrm{~cm}$ 末満 & 1 & 2 \\
\hline & & $5 \mathrm{~cm}$ 以上 & 0 & 0 \\
\hline \multirow{3}{*}{ 2008年5月 } & \multirow{3}{*}{ 再生 } & $2 \mathrm{~cm}$ 未満 & 5 & 0 \\
\hline & & $2 \mathrm{~cm}$ 以上, $5 \mathrm{~cm}$ 未満 & 0 & 0 \\
\hline & & $5 \mathrm{~cm}$ 以上 & 0 & 0 \\
\hline \multirow{3}{*}{\multicolumn{2}{|c|}{ 発生株頭数 }} & $0 \sim 2 \mathrm{~cm}$ & 26 & 26 \\
\hline & & $2 \mathrm{~cm}$ 以上, $5 \mathrm{~cm}$ 未満 & 10 & 19 \\
\hline & & $5 \mathrm{~cm}$ 以上 & $\begin{array}{r}0 \\
36 \\
\end{array}$ & $\begin{array}{r}4 \\
49 \\
\end{array}$ \\
\hline
\end{tabular}

認されていた。一方，全面散布タイプ-5・9 月，全面散布タ イプ-9月の試験区では，2008 年 5 月の段階でクズの再生が 確認されておらず植被率は０\%である。全面散布タイプの除 草剂は主に葉から吸収されるため，葉が展開していない 5 月 の散布では効果が低い。全面散布タイプの場合，葉が十分に 展開でき，貯蔵根に養分を蓄えられる 8９ 月の使用が効果 的である。処理回数は秋季の 1 回で十分だと考えられるが, 5 月と 9 月の 2 回散布することにより，翌春の枯れた多年生 ツルの量が少なくなる。そのため，翌春に他の植物の再生は 多く，処理法面を早期に自然回復させる効果はあるともいえ る。

株頭処理の 2 種類の除草剂は, 2007 年 5 月の施工後, 6 月 そして 8 月に見落としていた株頭および再生した株頭に追加 でそれぞれの薬剤で処理を行った。2008 年 5 月の調査では, 
滴下型には 5 箇所の新芽が出た株頭が確認され，植被率も 3 $\%$ 程度あった。一方，挿入型は 2008 年 5 月の調査でも新芽 の発生は確認されず植被率も0\%であった。

\section{2 株頭処理数の推移}

\section{2 .1 処理株頭数}

株頭処理の滴下型および挿入型の試験区で，処理した株頭 数を表 -4 に示す。いずれの処理区も見落としたもの，処理し たものから再生したものがある。試験区における最終的な株 頭数は滴下型で株頭径 $2 \mathrm{~cm}$ 未満の株頭が 26 株, $2 \mathrm{~cm}$ 以上 5 $\mathrm{cm}$ 未満の株頭が 10 株, $5 \mathrm{~cm}$ 以上の株頭が 0 株, 合計 36 株 であった。挿入型では, 株頭径 $2 \mathrm{~cm}$ 末満の株頭が 26 株, $2 \mathrm{~cm}$ 以上 $5 \mathrm{~cm}$ 未満の株頭が 19 株, $5 \mathrm{~cm}$ 以上の株頭が 4 株, 49 株であった。挿入型の試験区の方が，株頭径が大きいものが 多く，株頭数も多かった。樹木が若干生存しているような法 面では，多年生ツルの株頭の密度はおおよそ $0.3 \sim 0.5$ 株頭 $/ \mathrm{m}^{2}$ 程度であると予想される。

\section{2 .2 見落とし株頭数}

見落とした株頭数は， 2007 年 6 月の調查で滴下型が 2 株, 挿入型が 6 株であった。2007 年 10 月の調査では両方とも 0 株であった。株頭処理の場合，作業性を考えると冬季から春 季に施工するべきであるが，この場合，枯れ草の下になって いるので多年生ツルの株頭がどこにあるかの判断が難しい。 一方， 6 月には一年生ツルが生長し発見を容易にすることが わかった。

\section{2 .3 再生株頭数}

2007 年 6 月の調査結果では, 滴下型の再生株頭数は, 株 頭径 $2 \mathrm{~cm}$ 未満の株頭が 8 株, $2 \mathrm{~cm}$ 以上 $5 \mathrm{~cm}$ 未満の株頭が 10 株，合計 18 株であった。挿入型の再生数は，株頭径 $2 \mathrm{~cm}$ 未満の株頭が 2 株, $2 \mathrm{~cm}$ 以上 $5 \mathrm{~cm}$ 未満の株頭が 3 株, 合計 5 株であった。株頭径の大きいものが再生する割合が高かっ た。また，扦入型は滴下型よりも再生株頭数が少なく確実な 方法であることがわかった。

2007 年 8 月の調査では，滴下型の再生数は，株頭径 $2 \mathrm{~cm}$ 未満の株頭が 5 株, $2 \mathrm{~cm}$ 以上 $5 \mathrm{~cm}$ 未満の株頭が 1 株，合計 6 株であった。挿入型の再生数は, 株頭径 $2 \mathrm{~cm}$ 未満の株頭が 5 株, $2 \mathrm{~cm}$ 以上 $5 \mathrm{~cm}$ 未満の株頭が 2 株, 合計 7 株であった。 株径の小さいものが再生する割合が高く, 2007 年 6 月の調 査結果とは逆の傾向を示した。これは，5～6月は貯蔵根にた められた養分を中心に再生が行われるため，株頭径が大きい ものから再生しやすいが, 6〜8 月は新たに発生した一年生ツ ルから発生した葉の同化作用によって養分がつくられるた め，株頭径の小さいものからも再生すると考えられる。

2008 年 5 月の調査では, 滴下型の株頭径 $2 \mathrm{~cm}$ 未満の株頭 が 5 株のみ確認され, 挿入型は確認されなかった。滴下型は, 挿入型と比較して, 液体で株頭の外部から処理するため, 除 草効果が短い可能性がある。そのため, 2007 年 8 月に処理
した後，生き残った同化組織の働きによって 9〜10月に貯蔵 根が形成され，それが翌春の 2008 年 5 月に再生につながっ たと考えられる。滴下型では 9〜10月の休眠期直前に再度施 用することが必要であった可能性がある。

挿入型の方が，再生率が少ないことから滴下型より作業性 は劣るが, 確実に駆除が出来る可能性がある。しかし, 株頭 径 $2 \mathrm{~cm}$ 末満の小さい株頭は使用しにくく, 一年生ツルの株 頭には使用できないことから，滴下型と併用するのが確実な 処理につながると考えられる。

\section{4. まとめ}

3 種類の除草剂を使用して，5つの試験区を設置したクズ の駆除試験を行った。対策を行った試験区は, いずれもクズ の植被率を低減させ，ほぼ駆除が完了したと判断できる。し かし，同じ除草剂を使用しても，除草時期やクズの生育特性 によって効果が十分に発揮できない場合もあった。今回の試 験施工で, 全面散布タイプで除草する時は, クズ以外の植物 に与える影響を考慮することが必要である。また，株頭処理 タイプでは, 一回の施用ではなく, 複数回の施用と駆除確認 を繰り返すことが効果的であることがわかった。最終的な判 断は少なくとも今秋の調査結果から評価しなければならない が，急勾配法面においても，効率的かつ効果的にクズを駆除 することが可能である知見を得た。

2007 年 9 月の調査では, 株頭処理によってクズが衰退し た法面に, ヨモギや植栽したヤマブキなどが生育していたが, セイタカアワダチソウやヒメムカショモギなどの外来種も生 育していた。今後はクズの駆除と同時に緑の質を高める「再 生緑化」も重要な検討課題である。

最後に，これらの技術を体系化し，クズ処理システム（ク ズバスター）として，クズ処理サービスを提供していること を付け加えておく。

\section{引用文献}

1）亀山 章（1978）高速道路のり面の植生遷移におけるクズ群 落，緑化工技術，5（2）：39-42.

2）中島一好（2004）小里川ダムのり面の自然復元の取り組み, ダム技術, $218:$ 19-32.

3）中野裕司（2008）森林表土利用工・自然侵入促進工の問題 · 課題と提案, 日本緑化工学会 斜面緑化研究部会・積雪寒冷地 緑化研究部会 第 1 回合同研究会要旨集 : 8-9.

4）田中 淳，山田 守 (2004) ダム堤体周辺の岩盤切土法面にお ける連続繊維補強土に植栽した樹木の生育特性, 日本緑化工学 会誌，30（2）：370-376.

5）田中 淳・山田 守（2005）表土を利用した法面緑化事例とそ の問題点, 日本緑化工学会誌，31（1）：99-102. 